\title{
Developing Blight-Tolerant American Chestnut Trees
}

\author{
William A. Powell, ${ }^{1,2}$ Andrew E. Newhouse, ${ }^{2}$ and Vernon Coffey ${ }^{2}$ \\ ${ }^{1}$ American Chestnut Research and Restoration Project, College of Environmental Science and Forestry, \\ Syracuse, New York 13210, USA \\ ${ }^{2}$ Department of Environmental and Forest Biology, College of Environmental Science and Forestry, \\ State University of New York, Syracuse, New York 13210, USA \\ Correspondence: wapowell@esf.edu
}

\begin{abstract}
An invasive fungal pathogen has reduced the American chestnut (Castanea dentata), once a keystone tree species within its natural range in the eastern United States and Canada, to functional extinction. To help restore this important canopy tree, blight-tolerant American chestnut trees have been developed using an oxalate oxidase-encoding gene from wheat. This enzyme breaks down oxalate, which is produced by the pathogen and forms killing cankers. Expressing oxalate oxidase results in blight tolerance, where the tree and the fungus can coexist, which is a more evolutionarily stable relationship than direct pathogen resistance. Genetic engineering (GE) typically makes a very small change in the tree's genome, potentially avoiding incompatible gene interactions that have been detected in some chestnut hybrids. The GE American chestnut also retains all the wild American chestnut's alleles for habitat adaptation, which are important for a forest ecosystem restoration program.
\end{abstract}

Forest ecosystems are being transformed by F invasive species through the elimination or broad degradation of ecological function of tree species (Lovett et al. 2006, 2016). These problems may be exacerbated by climate change (Dukes et al. 2009). We believe the ability to mitigate this unprecedented threat to the biodiversity and economic value of these ecosystems will require the integration of multiple approaches, including genetic engineering (GE) (Woodcock et al. 2018). A model for this approach is provided by the American chestnut (Castanea dentata), which was devastated by a chestnut blight caused by an invasive fungal pathogen. Researchers at the State University of New York's
College of Environmental Science and Forestry (SUNY-ESF), with the help of many collaborators from various universities, nongovernmental organizations, and the general public, have used GE to develop blight-tolerant American chestnut trees. Pending approval from regulatory agencies, we hope to facilitate introgression of this blight tolerance trait into the surviving remnant American chestnut populations through controlled breeding and restoration plantings. The ultimate goal is a diverse, self-sustaining population of blight-tolerant American chestnut in the forests of eastern North America. This is an exciting and unique endeavor because, to our knowledge, this is the first bioengineered

Editor: Pamela C. Ronald

Additional Perspectives on Engineering Plants for Agriculture available at www.cshperspectives.org

Copyright (C) 2019 Cold Spring Harbor Laboratory Press; all rights reserved; doi: 10.1101/cshperspect.a034587

Cite this article as Cold Spring Harb Perspect Biol 2019;11:a034587 
W.A. Powell et al.

organism developed specifically with the goal of ecological restoration. It also exemplifies the unique potential for this technology to be used for environmental and cultural benefits outside agriculture. This review will describe the ecological problem of chestnut blight, our search for solutions, scientific progress and success, and current efforts to put this solution into practice.

\section{THE PROBLEM}

The American chestnut (Fig. 1) was once a keystone tree species within its natural range in the eastern United States and Canada. In many areas, it was either the dominant or codominant canopy tree species (Anagnostakis 1982; Smith 2000; Dalgleish et al. 2015; Collins et al. 2017). It was a fast-growing and long-lived tree that produced a uniquely consistent mast crop of nuts for both human and wildlife consumption (Diamond et al. 2000), could be harvested for valuable lumber and tannins, and was considered a foundational species for wildlife habitat (Hardin et al. 2001; Paillet 2002). The American chestnut's ecological role even extended to carbon sequestration and biomass conversion (Jacobs et al. 2009). The American chestnut also has a unique social value (Davis 2005), memorialized in songs (e.g., "Chestnuts Roasting on an Open Fire"), street and place names (the near-ubiquitous Chestnut Street), and literature (as in this excerpt from Thoreau's Walden):

When chestnuts were ripe I laid up half a bushel for winter. It was very exciting at that season to roam the then boundless chestnut woods of Lincoln,- - they now sleep their long sleep under the railroad, - with a bag on my shoulder, and a stick to open burs with in my hand, for I did not always wait for the frost, amid the rustling of leaves and the loud reproofs of the red squirrels and the jays, whose half-consumed nuts I sometimes stole, for the burs which they had selected were sure to contain sound ones. Occasionally I climbed and shook the trees. They grew also behind my house, and one large tree, which almost overshadowed it, was, when in flower, a bouquet which scented the whole neighborhood, but the squirrels and the jays got most of its fruit; the last coming in flocks early in the morning and pick-

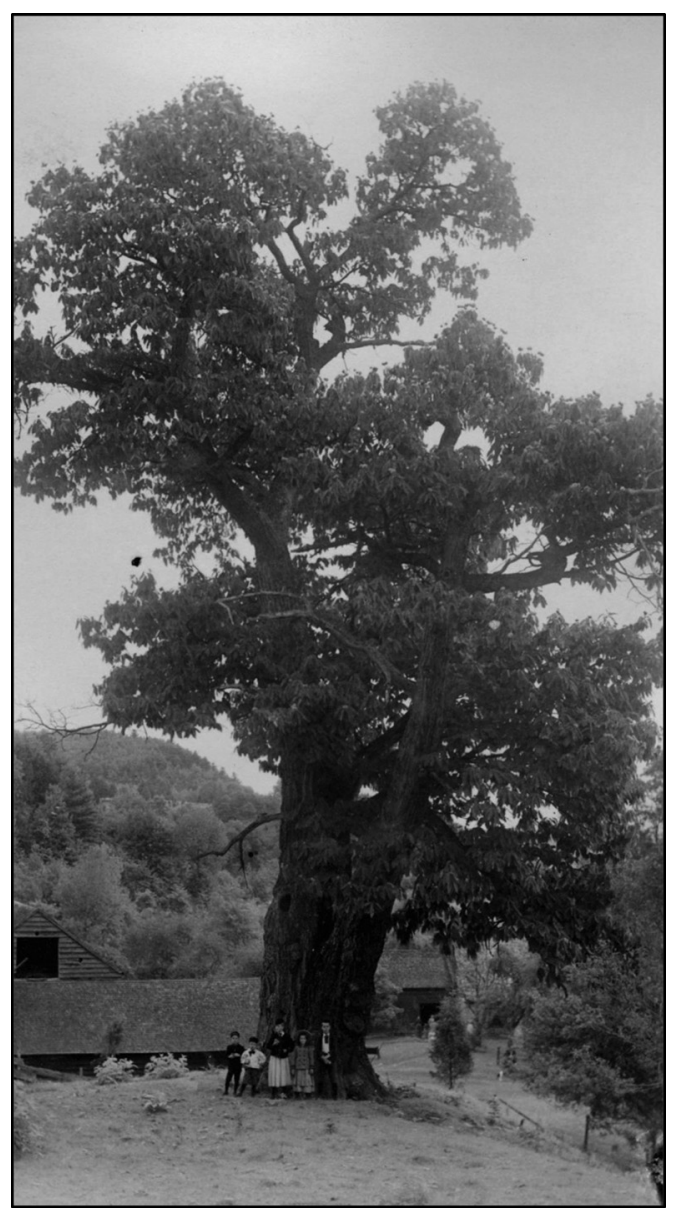

Figure 1. Large American chestnut tree (Paul farm) in Hurley, NY. (Photo provided by Gail Whistance. Photo credit William Cressy Vrooman (1857-1939); image entitled "American Chestnut Tree c. 1889-1895." Print from glass plate negative. Location: Ten Eyck bouwerie [Bouwerie is the Dutch word for farm]. Hurley Mountain Road, Hurley, NY. Original image and information courtesy of the Hurley Heritage Society. Collection of Marguerite Veeder Yates Parker, granddaughter of John Wynkoop Veeder. Gift of her granddaughter Ellen McCoy Messick.)

ing the nuts out of the burs before they fell, I relinquished these trees to them and visited the more distant woods composed wholly of chestnut. These nuts, as far as they went, were a good substitute for bread.

Unfortunately, a little over a century ago, an invasive fungal pathogen called Cryphonectria parasitica was introduced from Asia into the 


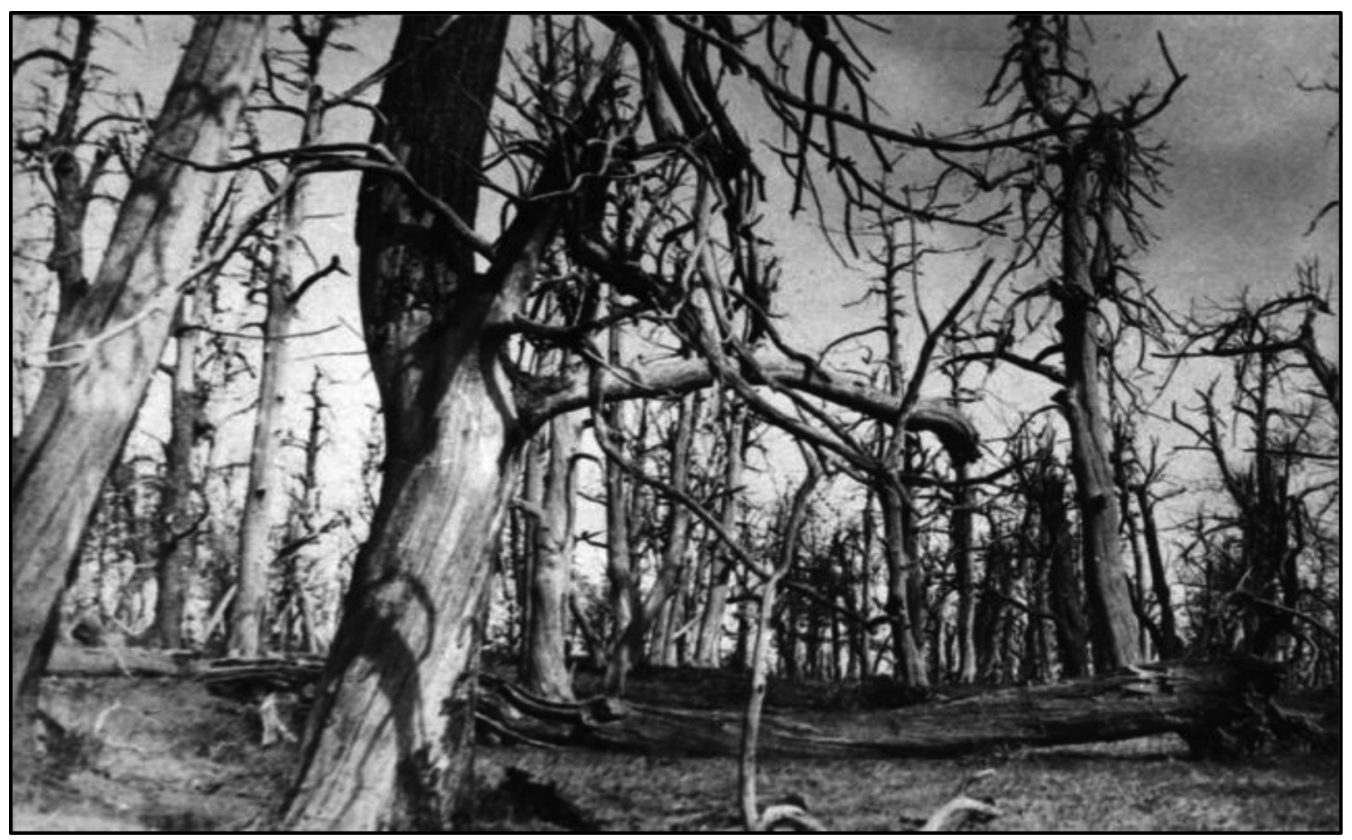

Figure 2. Example of a pure American chestnut stand a few years after the chestnut blight went through. (Photo: A ghost forest of blighted American chestnuts in Virginia provided by the Library of Congress Prints and Photographs Division.)

United States though the port of New York (Anagnostakis 1987). Within about 50 years of its discovery in 1904, the chestnut blight spread throughout the American chestnut's natural range, killing around $90 \%$ of the population (Fig. 2). Survivors were reduced from a keystone canopy species to an insignificant understory tree that rarely produces viable nuts, making the American chestnut functionally extinct.

\section{SEARCHING FOR A SOLUTION}

Many approaches to address chestnut blight have been tried over the years without significant success. One interesting approach is a biocontrol method that causes the fungus to become hypovirulent (less aggressive). Hypovirulence, caused by a virally compromised strain of the fungus, can spread by hyphal anastomosis (a fusion where the hyphae share cytoplasm) in cankers on infected trees, slowing or stopping the growth of the fungal infection (see Milgroom and Cortesi 2004 and Van Alfen 2018 for reviews of hypovirulence). This approach has had better success in Europe with Castanea sativa than in the United States with $C$. dentata. Problems include the limited success of viral transfer between different vegetatively incompatible strains of the fungus, and the ability of the fungus to establish new, uncompromised infections. This approach is still being pursued in the United States. Recent research has described a new modification using genetically engineered "super donor" fungal strains that help to overcome some of these difficulties (Stauder et al. 2019). Hypovirulence may assist in keeping surviving trees alive long enough to breed with blight-tolerant strains of American chestnut, but using current methods is unlikely to provide meaningful blight control in the United States on a landscape scale.

\section{Asian Chestnut Plantings}

Asian chestnut species such as Japanese chestnut (Castanea crenata) and Chinese chestnut (Castanea mollissima) coevolved with C. parasitica and have varying levels of quantitative re- 
W.A. Powell et al.

sistance to the chestnut blight. These chestnuts trees, primarily Chinese chestnut, have been widely distributed for over 100 years and many are planted in orchards throughout the United States for nut production (Hunt et al. 2012). There are few reports of natural regeneration of these introduced species in unmanaged forests (Jaynes 1967; Anagnostakis and Hillman 1992; Miller et al. 2014). The few areas where Chinese chestnuts have been established were not optimal American chestnut sites, with shallow soils that stunt the growth of the competitive tree species allowing the shorter Chinese chestnut trees to reach the canopy.

\section{Hybrid Breeding Programs for Blight Resistance}

In 1921, A.H. Graves started crossing American chestnut with a variety of Asian chestnut species, which was continued by the Connecticut Agricultural Experiment Station in 1950. This eventually produced what has become known as the "Graves" tree used by The American Chestnut Foundation (TACF) in their backcross breeding program, as well as other genetic lines derived from Chinese $\mathrm{x}$ American chestnut hybridization (Graves 1940; Anagnostakis 2012).

In 1922, breeding work for blight resistance also began under the United States Department of Agriculture (USDA) Office of Forest Pathology, with American chestnut and Chinese chestnut hybrids selected for timber-type growth form (tall and straight, a hallmark of the American chestnut) and blight resistance (Burnham et al. 1986). From that effort, several promising first-generation Chinese $\mathrm{x}$ American hybrid trees were generated, including what has become known as the "Clapper" tree, which for several decades did exhibit good growth and slower progression of chestnut blight, yet eventually did die from it. Like the "Graves" tree, the "Clapper" was later used as starting material for the TACF backcross breeding program. The USDA hybrid breeding program was abandoned in 1960 (Diller and Clapper 1965).

None of these early programs succeeded in producing a fast growing, timber-type tree with good blight resistance; every candidate fell short in at least one of these respects (Diller and Clapper 1969; Burnham et al. 1986; Anagnostakis 2012). Hybrid breeding can also result in complications, with respect to a restoration tree, such as internal kernel breakdown (IKB) (Fulbright et al. 2014), male sterility (Sisco et al. 2014), and intermediate traits (Cipollini et al. 2017).

\section{Mutational Breeding for Blight Resistance}

Starting in the 1950s and proceeding into the 1970s, W. Ralph Singleton and Albert Dietz exposed chestnut seeds to radiation, with the hope of inducing a mutation that would confer blight resistance to the resulting tree (Dietz 1978; Burnworth 2002; Curry 2014). This technique had been used by Singleton and others on a wide variety of crops, in many cases resulting in disease resistance or other desirable traits, some of which are still agriculturally important today. Chestnut seeds collected by Dietz were irradiated at Brookhaven National Laboratory and other facilities, and over 10,000 resulting trees were planted in orchards ranging over seven states (Dietz 1978), but no measurable resistance to chestnut blight has been reported in these trees or their offspring. Because this technology was and is not regulated, offspring and re-sprouts from some of these irradiated trees may still be present at various locations today.

\section{Backcross Breeding of Hybrids}

In 1983, TACF was founded as a coalition of plant scientists and laypersons interested in the preservation of the species. Soon thereafter, three of the foundation's scientists published an extensive paper describing the foundation's breeding plan to incorporate resistance genes from the Chinese chestnut (Burnham et al. 1986). Although earlier programs had the goal of replacing American chestnuts with simple hybrids or pure Asian species (Hepting 1974), the "Burnham plan" proposed a systematic program of backcrossing F1 hybrid trees with pure American chestnut trees, selecting for blight resistance and American phenotype at each step. To get a jump start, they began with the "Graves" and "Clapper" hybrid trees from the two previ- 
ous hybrid breeding programs. The goal was a population of trees with the phenotype of American chestnut and the blight resistance of the Chinese chestnut.

The original plan was based on a hypothesis of two resistance genes (Burnham et al. 1986). Under that assumption, the resistance alleles could be preserved through backcrossing, and selected trees from an intercross generation would be homozygous at both resistance loci, giving them resistance matching Chinese chestnuts. However, updated data suggests that three or more separate loci contribute to quantitative blight resistance. Each additional gene involved reduces the probability that all resistance alleles will be inherited and therefore increases the number of trees needed at each generation. Although the breeding program has had success in capturing many of the morphological features of the American chestnut (Diskin et al. 2006), to date the best candidate trees have achieved a level of blight resistance intermediate between the two parent species, greater than wild-type American chestnut controls but less than Chinese chestnut controls (Steiner et al. 2017). These trees are continuing to be improved with further breeding to other sources of resistance, including some with the blight-tolerant transgenic American chestnut trees.

\section{INCORPORATING THE TOOLS OF GENETIC ENGINEERING}

\section{History of the Project}

The effort to genetically engineer American chestnut had an unusual beginning. In 1989, two members of the newly formed New York chapter of TACF-NY, Herb Darling and Stan Wirsig, met with Dr. Charles Maynard and Dr. William Powell (faculty at SUNY-ESF). The TACF members represented laypeople seeking researchers who could use the latest tools of GE to complement the ongoing TACF backcross breeding program. Dr. Maynard had experience in forestry and black cherry tissue culture (Tricoli et al. 1985; Fuernkranz et al. 1990; Maynard 1994) and Dr. Powell had experience in molecular biology and virulence of the chestnut blight fungus (Hansen et al. 1985; Powell and Van Alfen 1987a,b; Gobbi et al. 1990). Encouraged by the interest from TACF-NY members, in 1990, Dr. Maynard and his students, collaborating with Dr. Scott Merkle at the University of Georgia (Merkle et al. 1991), began to develop the tissue culture and transformation methods needed to add genes to the chestnut genome. Dr. Powell and his students sought and tested putative resistance genes. This chapter will focus on the search for resistance genes; further information on tissue culture methods has been described previously by Dr. Maynard and his students (Xing et al. 1997, 1999; Polin et al. 2006; Rothrock et al. 2007; Oakes et al. 2016a,b).

One significant advantage of GE compared to traditional hybrid and backcross breeding is that there is a much smaller change to the genome with respect to gene alleles that can influence traits that make the American chestnut adapted to its habitat. This means that all the gene alleles normally found in given American chestnut trees are retained. For example, the American chestnut's height at maturity allows it to compete for light in a dense forest canopy, whereas the Chinese chestnut, often used in breeding programs, has a much shorter stature. TACF's backcross breeding program selects trees for American phenotype using features such as leaf, twig, and bud morphology (Diskin et al. 2006). However, trees are selected at a young age in an orchard; other important ecological attributes cannot be tested until these trees reach maturity in a forest setting. Insertion of a small segment of DNA through GE, without interrupting any existing genes, allows the offspring to retain all the alleles for height and other adaptations.

\section{Searching for Genes}

There are two general approaches to identifying putative resistance-enhancing genes. One is to search for the genes that confer resistance in the related, blight-resistant Asian species of chestnut. This approach requires significant genomic and bioinformatics capabilities that were not available in the early 1990s. In addition, no single gene from the blight-resistant Asian species 
W.A. Powell et al.

would likely confer full resistance, as the resistance in that species is quantitative and requires multiple genes working together (Kubisiak et al. 1997; Steiner et al. 2017). Instead, we took a functional approach, focusing the mechanism of fungal infection. Knowing the basics about how the fungal pathogen attacks the tree (Havir and Anagnostakis 1983; Chen et al. 2010), we sought out genes that would protect the tree from blight infections. Using this approach, it was the function of the gene, not the source, that was important. The goal was to find a single, dominant gene that would protect the tree from the blight at a level equal to, or possibly higher than, the Asian chestnut species.

In the early 1990s, there were few identified genes available for testing resistance to fungal pathogens. At the time, the most common genes used in transgenic plants were chitinases and $\beta-1,3$-endoglucanases (e.g., Brogue et al. 1991; Yoshikawa et al. 1993). We decided to take a different route and began working with antimicrobial peptides (AMPs), which naturally protect many animals from infections (Zasloff 1987; Jia et al. 2000; Lamberty et al. 2001; Linde et al. 2008), and are also part of the innate immunity in most organisms (Gordon and Romanowski 2005). Because these peptides were very small, it was feasible to synthesize and test modified sequences in the laboratory. We tested several synthetic designs based on the protein structure of magainin-type AMPs found in frog skin. Using our own designs allowed us to enhance antifungal activity while reducing potential effects on animals (i.e., hemolytic activity [Powell et al. 1995, 2000]). The best designs could then be reverse engineered into genes for testing in plants (Liang et al. 2001, 2002; Newhouse et al. 2007).

While this early research with synthetic AMPs showed some success in conferring resistance to fungal infection, we soon learned that public acceptance is an equally important consideration. Though the peptides used were synthetic in origin, and not cloned directly from a frog or any other organism, they became known as the "frog genes" with all the problematic public perceptions that this engendered. Responding to public feedback, this line of research was eventually abandoned for a more effective and publicly acceptable gene.

A eureka moment occurred while reading a book of abstracts from the 1997 Annual Meeting of the American Society of Plant Physiologists, with an abstract entitled "Expression of oxalate oxidase in transgenic plants provides resistance to oxalic acid and oxalate-producing fungi." Oxalate (or oxalic acid) at a chestnut blight canker margin helps lower the $\mathrm{pH}$ from a normal 5.5 to a toxic 2.8 , binds calcium, inhibits lignin formation (Welch et al. 2007), and may inhibit the oxidative burst in the host (Cessna et al. 2000). Oxalate had been linked to virulence in $C$. parasitica when studying hypovirulence (Havir and Anagnostakis 1983, 1985); this link was later confirmed in knockout mutants of the pathogen (Chen et al. 2010). We immediately began working with a wheat oxalate oxidase $(\mathrm{OxO})$ gene provided by Dr. Randy Allen (Texas Tech University). At that time, the chestnut transformation protocols were still being optimized, so the initial tests were performed in a model tree, hybrid poplar, where we demonstrated that the OxO gene could enhance resistance to another oxalate-producing fungal pathogen, Septoria musiva (Liang et al. 2001). Successful transformation of American chestnut followed soon thereafter (Polin et al. 2006), and we planted the first transgenic American chestnut trees in field trials under USDA permits in 2006.

\section{Why Is Oxalate Oxidase an Ideal Gene for American Chestnut?}

We have tested over 30 transgenes, mostly from Chinese chestnut, in conjunction with various promoters, producing hundreds of transgenic events in American chestnut. However, the constitutively expressed $\mathrm{OxO}$ gene has demonstrated the best results to date and will soon be submitted for U.S. Federal regulatory review. There are other transgenic events in the development pipeline with different promoters (e.g., the win3.12 wound/pathogen-inducible promoter), and combinations of transgenes to try to protect the tree from other chestnut pathogens, such as Phytophthora cinnamomi. 
There are many advantages to using the oxalate oxidase to confer blight tolerance. First and most important, oxalate oxidase has been shown to be effective at protecting the American chestnut tree from the oxalate produced by C. parasitica (Zhang et al. 2013; Newhouse et al. 2014; see examples in Figs. 3 and 4). A single copy of the gene expressed over a certain threshold level can provide blight tolerance similar to Chinese chestnut controls. Because this new trait is inherited like a dominant allele, it can be used to rescue existing genetic diversity and local adaptations in the surviving remnant population of the American chestnut. When using pollen from a transgenic blight-tolerant tree to outcross to a surviving "mother" tree, approximately half the offspring inherit the blight tolerance along with half the nuclear genotype and all the cytoplasmic genes in the chloroplasts and mitochondria from the wild mother tree. Nuts or seedlings that inherit the $\mathrm{OxO}$ gene can be identified with a simple assay (Zhang et al. 2013). Coordinated outcrossing to a variety of "moth- er" trees throughout the natural range of the American chestnut will add more diversity and local adaptations to the population (J Westbrook, J Holiday, A Newhouse, et al., in prep.). This process differs from traditional breeding approaches where resistance is provided by genes that are either recessive or intermediately dominant. In that scenario, full blight resistance is only expressed by individuals that are homozygous for all resistance alleles. The restoration population, therefore, must remain closed because every outcrossing dilutes the resistance and requires intercrossing to build back the full resistance. Thus, GE simplifies the rescue of genetic diversity for use in restoration because about half the offspring from outcrossing inherit full blight tolerance and no dilution occurs.

Second, oxalate oxidase provides "tolerance" to the blight not by killing the pathogen, but instead by protecting the tree from the damaging oxalate produced by the pathogen (Fig. 4). The tree and the fungus can coexist, as is the case with Asian chestnut species in the native range

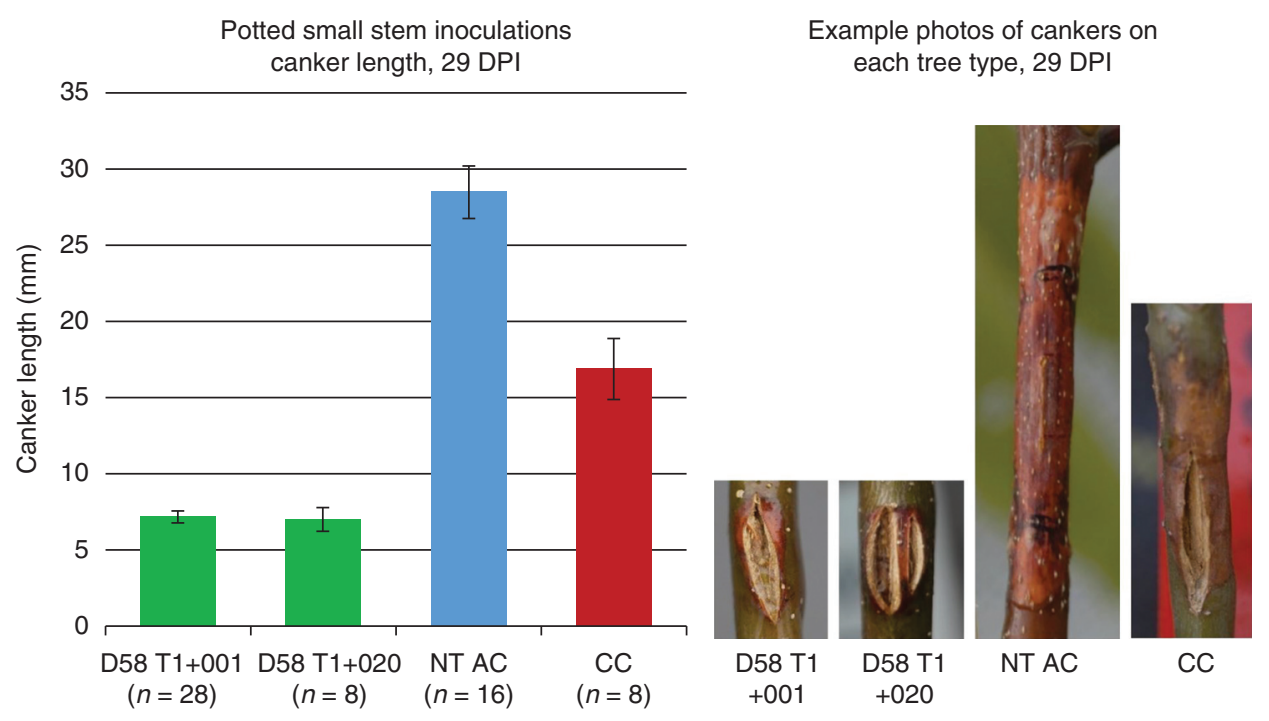

Figure 3. Mean canker height (left) on stem inoculations of potted Darling $58 \mathrm{~T} 1$ trees compared to nontransgenic controls, with example photos (right) of cankers on each tree type. Measurements and photos taken 29 days postinoculation (DPI). Error bars indicate \pm 1 standard error of the mean. Note in the photos that the Darling 58 transgenic stems were visibly infected by blight (orange color immediately surrounding the wound) but the infection did not spread far beyond the wound or cause damage like that on the nontransgenic controls. The wounds on the Darling 58 and Chinese stems appear worse (splitting open) because the stems are still growing, whereas the nontransgenic American stem tissue surrounding the wound is completely dead as a result of blight. 
W.A. Powell et al.

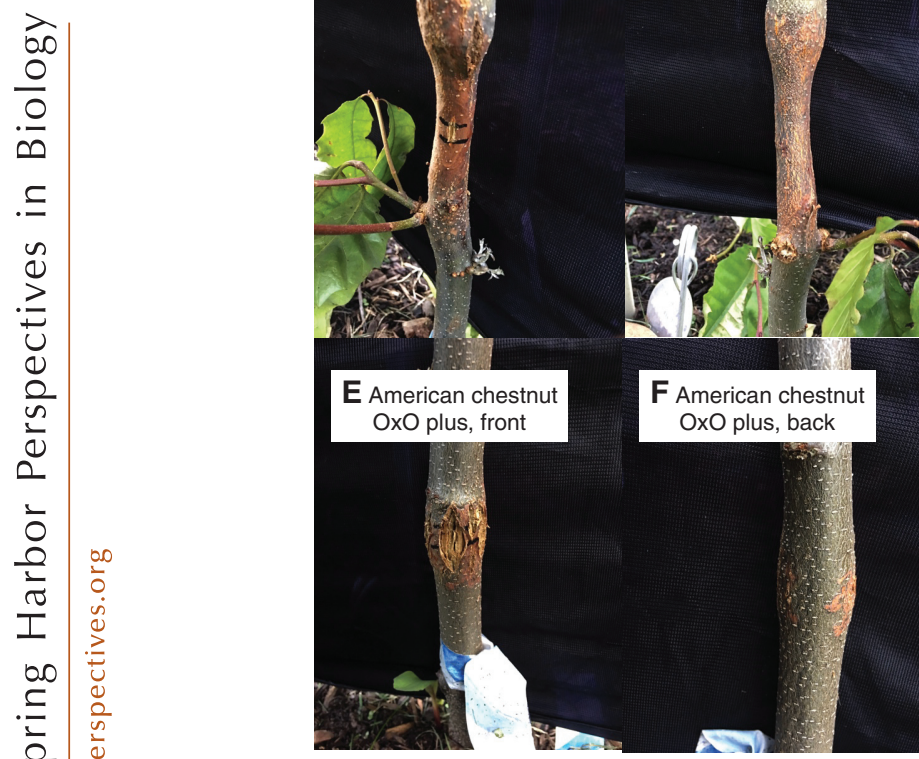

Figure 4. Two-year-old stems ( $\sim 1 \mathrm{~cm}$ diameter $)$ inoculations with Cryphonectria parasitica strain EP155. $(A, B)$ Resistant Chinese and susceptible American chestnut, respectively, 76 days postinoculation. $(C, D)$ Front and back, respectively, "Darling" American chestnut T1 offspring that did not inherit the oxalate oxidase gene, 74 days postinoculation. ( $E$, F) Front and back, respectively, "Darling" American chestnut $\mathrm{T} 1$ offspring that did inherit and expressing the oxalate oxidase gene. Black marker lines in $C$ and $E$ represent the $0.5 \mathrm{~cm}$ wound that was originally inoculated.

of the blight fungus. This is important because chestnuts are long-lived trees, so effective blight protection must be sustainable over the lifetime of the tree for it to provide all its ecological services. Even though we are using a single gene, tolerance is a very evolutionarily stable relation- ship because it does not provide a strong selective pressure for the pathogen to overcome this defense (Rausher 2001; Woodcock et al. 2018). To date, we have not seen a report of a pathogen that uses oxalate as a virulence factor overcome the plant tolerance conferred by oxalate oxidase; so it is unlikely that this will occur in C. parasitica.

Finally, the oxalate oxidase enzyme is very common in both wild and cultivated plants (Table 1). This ubiquity helps demonstrate its safety in food, feed, and to the environment. Knowing that it is consumed daily by billions of people, livestock, and wildlife should ease public acceptance. The amount of oxalate oxidase potentially introduced to the human diet from transgenic chestnut would be dwarfed by the amount consumed from other sources.

\section{REGULATORY OVERSIGHT}

The section is from the authors' perspective, specific and updated regulatory details should be clarified directly with the appropriate agencies.

In the United States, regulation of genetically engineered plants falls under the federal coordinated framework consisting of one or more the following agencies: USDA, the Food and Drug Administration (FDA), and the United States Environmental Protection Agency (EPA). This usually means that at least one of the regulatory agencies reviews each newly developed genetically engineered plant, but often more than one agency is involved, as is the case for the transgenic, blight-tolerant American chestnut.

GE of agricultural crops is widespread, so the companies that produce these products have become adept at navigating the relevant regulatory processes. In contrast, most university faculty researchers lack training or resources for working with the federal regulatory processes for genetically engineered plants. Many potentially useful crops have been developed at universities using the tools of GE, but few have even attempted federal regulatory review. Examples (limited to crops transformed with the oxalate oxidase) include hybrid poplar (Liang et al. 2001), soybean (Donaldson et al. 2001), corn (Ramputh 
Developing Blight-Tolerant American Chestnut Trees

Table 1. Samples of oxalate oxidase isozymes found in plants and other organisms

\begin{tabular}{|c|c|c|}
\hline Common name & Scientific name & References \\
\hline \multicolumn{3}{|l|}{ Cultivated food plants } \\
\hline Peanut & Arachis hypogaea & Wang et al. 2010 \\
\hline Oat & Avena sativa & Lane et al. 1991 \\
\hline Beet & Beta vulgaris & Obzansky and Richardson 1983 \\
\hline Tea & Camellia sinensis & Fu et al. 2018 \\
\hline African oil palm & Elaeis guineensis & Rusli et al. 2015 \\
\hline Strawberry & Fragaria ananassa & Dahiya et al. 2010 \\
\hline Barley & Hordeum vulgare & Sugiura et al. 1979 \\
\hline Banana & Musa paradisica & Anjum et al. 2014 \\
\hline Rice & Oryza sativa & Carrillo et al. 2009 \\
\hline Date palm & Phoenix dactylifera & $\begin{array}{l}\text { LOC103698783 oxalate oxidase 1-like } \\
\text { (Phoenix dactylifera [date palm]) }\end{array}$ \\
\hline Peach and apricot & Prunus spp. & Liang et al. 2010 \\
\hline Sorghum & Sorghum bicolor & Satyapal and Pundir 1993 \\
\hline Spinach & Spinacia oleracea & Laties 1950 \\
\hline Cacao & Theobroma cacao & Gesteira et al. 2007 \\
\hline Wheat & Triticum aestivum & Lane et al. 1993 \\
\hline Corn & Zea maize & Vuletić and Šukalović 2000 \\
\hline \multicolumn{3}{|l|}{ Wild plants and microbes } \\
\hline Mosses & $\begin{array}{l}\text { Six spp. (genera include: Mnium, } \\
\text { Hylocomium, Eurohynchium, } \\
\text { Rhytidiadelphus) }\end{array}$ & Laker et al. 1980 \\
\hline Goatgrass & Aegilops tauschii subsp. tauschii & $\begin{array}{l}\text { Oxalate oxidase GF-2.8 (Aegilops } \\
\text { tauschii subsp. tauschii) }\end{array}$ \\
\hline Spiny amaranth & Amaranthus spinosus & Goyal et al. 1999 \\
\hline Ramie & Boehmeria nivea & Xuxia et al. 2012 \\
\hline Bougainvillea & Bougainvillea spectabilis & Srivastava and Krishnan 1962 \\
\hline Stiff brome & Brachypodium distachyon & $\begin{array}{l}\text { LOC100841795 oxalate oxidase } 1 \\
\text { (Brachypodium distachyon } \text { [stiff } \\
\text { brome]) }\end{array}$ \\
\hline Rubber bush & Calotropis procera & Freitas et al. 2017 \\
\hline White rot fungus & Ceriporiopsis subvermispora & Aguilar et al. 1999 \\
\hline Insulin plant & Costus pictus & Sathishraj and Augustin 2012 \\
\hline Moss & Hypnum triquetrum & Houget et al. 1927 \\
\hline Perennial ryegrass & Lolium perenne & Davoine et al. 2001 \\
\hline Endophytic bacterium & Ochrobactrum intermedium CL6 & Kumar and Belur 2016 \\
\hline Bacteria & Pseudomonas sp. OX-53 & Koyama 1988 \\
\hline Azalea & Rhododendron mucronatum & Sakamoto et al. 2015 \\
\hline Castor bean & Ricinus communis & $\begin{array}{l}\text { LOC107261123 oxalate oxidase GF-3.8- } \\
\text { like (Ricinus communis [castor bean]) }\end{array}$ \\
\hline Split-gill mushroom & Schizophyllum commune & $\begin{array}{l}\text { SCHCODRAFT_15706 oxalate oxidase } \\
\text { (Schizophyllum commune H4-8) }\end{array}$ \\
\hline Dermatophytic fungus & Trichophyton rubrum & $\begin{array}{l}\text { TERG_03492 oxalate oxidase } \\
\quad \text { (Trichophyton rubrum CBS 118892) }\end{array}$ \\
\hline $\begin{array}{l}\text { Wild einkorn (wheat } \\
\text { progenitor) }\end{array}$ & Triticum urartu & $\begin{array}{l}\text { Oxalate oxidase GF-2.8 (Triticum } \\
\text { urartu) }\end{array}$ \\
\hline Narrowleaf cattail & Typha angustifolia & Du et al. 2018 \\
\hline
\end{tabular}


W.A. Powell et al.

et al. 2002), sunflower (Hu et al. 2003), tomato (Walz et al. 2008), rice (Molla et al. 2013), and taro (He et al. 2013). The university-developed crop plant that may have come closest was peanut (Hu et al. 2015, 2016), which was submitted to the USDA but later withdrawn after facing the complications and high costs of the EPA registration.

Like most university professors, we also began this process with virtually no regulatory background in this process and have relied heavily on feedback from the three agencies directly, the USDA IR4 Project, and volunteer or reduced-fee consultants. It has taken about 3 years to thoroughly understand the regulations, to complete additional experiments needed for regulatory review, and to start writing extensive dossiers with supporting material for the blight-tolerant American chestnut. Future restoration projects involving GE would be streamlined by a better understanding of this system, so we have been involving students and research collaborators throughout the whole process.

Regulatory Review Processes

USDA

The USDA, through its Animal and Plant Health Inspection Service (APHIS) has responsibility for protecting agriculture from pests and diseases. Through the Plant Protection Act and the Animal Health Protection Act (AHPA), the USDA derives regulatory authority of biotechnology products that have the potential to pose a risk to agricultural plant and animal health. The USDA also oversees all our field trial planting permits.

As with all the regulatory agencies, the first question is, "Are we regulated?" This was easily answered because we used Agrobacterium-mediated transformation. Because the disarmed Agrobacterium tumefaciens strain we used was developed from a plant pathogen, the transgenic American chestnut falls under USDA regulation. Newer bioengineering techniques that do not involve plant pests may not be subject to the same review process.
As of this writing, a petition for nonregulated status is being prepared for the USDA. The final petition will include an extensive background on the biology and ecology of American chestnut, molecular characterization of the transgenic events, enzyme quantification, blight tolerance assays, growth comparisons, and several ecological studies. Two such ecological studies published recently are a wood frog tadpole experiment observing feeding on chestnut leaf litter (Goldspiel et al. 2018) and another examining native seed germination and mycorrhizal root colonization in the presence of transgenic chestnut tissue (Newhouse et al. 2018). To date, no significant environmental differences have been found between the transgenic and wild-type American chestnut.

The first step in submission is a review for completeness and editing as needed. Subsequent steps include a 60-day open comment period on the petition, preparation of the Plant Pest Risk Act (PPRA) evaluation by the USDA, preparation of an Environmental Impact Statement (EIS) by the USDA's National Environmental Policy Act (NEPA) team, another open comment period on the EIS, revision of documents and response to comments, and then a final decision. It is impossible to accurately predict how long this process will take, but a reasonable estimate based on other recent submissions is approximately 18 to 24 months. The decision (also pending decisions by other agencies) will determine whether we can proceed to public distribution and ecosystem restoration, or whether more testing needs to be completed and reviewed.

FDA

The FDA's authority relative to our blight-tolerant American chestnut trees is based on its mission to assure the safety of foods and food ingredients for humans and animals, specifically under the adulteration provisions (section 402 (a)(1)) and the food additive provisions (section 409) of the Federal Food, Drug and Cosmetic Act (FD\&C Act).

FDA review of transgenic plant products is technically voluntary, but to our knowledge, all 
transgenic food plants available in the United States today have been through this review. Because the American chestnut produces a nut that can be used in food and feed, we will submit our trees for their review. The approval sought from the FDA through the premarket consultation process is a determination as to whether our transgenic trees meet the standards of safety for food additives and GRAS (generally recognized as safe) substances as well as the adulteration section provisions of the FD\&C Act.

\section{EPA}

The EPA is responsible for protecting human health and the environment. EPA's regulatory authority relative to our blight-tolerant American chestnut trees is derived from the Federal Insecticide, Fungicide, and Rodenticide Act (FIFRA), which was originally intended to address regulation of pesticides, but has expanded first to include plant pesticides and later modified into plant incorporated protectants (PIPs). Examples of PIPs registered with the EPA include Cry proteins from Bacillus thuringiensis (Bt) that have been incorporated into many commercially grown crops.

Of the three agencies comprising the coordinated framework, the EPA is the only one that charges fees. Levied under the Pesticide Registration Improvement Extension Act (PRIA), these include registration fees (covering initial reviews) and maintenance fees (covering annual reports). Land grant universities and some governmental institutions have reduced rates or are exempt from at least some of these fees, but many universities or nonprofits would still be responsible for some or all of the costs. These fees were implemented when primarily forprofit commodities were being regulated, but they become problematic with public restoration programs such as the American chestnut project and other not-for-profit applications. For example, it is not clear who would or should pay ongoing maintenance fees for a wild, unowned, not-for-profit restoration tree replicating on its own in the wild. Some form of federal rule change will likely be required to allow the use of GE for disease tolerance in wild organ- isms. This has presented a new paradigm for the regulators to consider.

For OxO-expressing American chestnuts, the first question raised with the EPA is whether we should be also regulated by this agency. This revolves around the EPA definition of a pesticide, and whether $\mathrm{OxO}$, which protects the tree from oxalate without harming the fungus, meets this definition. We have been engaged in discussions surrounding this question for over a year to date. Although we believe that $\mathrm{OxO}$ is not a pesticide (even as defined in FIFRA), if the EPA rules oxalate oxidase to be a pesticide under FIFRA, we will proceed accordingly, seeking a reasonable path to distribution of restoration trees that can be freely planted, bred, and shared.

The process currently underway for the American chestnut will lay very important groundwork for any future restoration of trees or other organisms using this technology. The outcomes have the potential to either encourage or stifle future innovation using biotechnology to adapt to new invasive pests.

\section{NEXT STEPS}

We have begun initial outcrossing of transgenic chestnuts to wild-type American chestnut mother trees and have reached the T2 (second outcross) generation as of 2018. Some of the first seedlings from this generation will comprise part of a multisite, long-term ecological research project to be initiated in 2019 . We are also preparing trees, scions for grafting, and/or pollen to be ready for public distribution pending regulatory approvals. These may come from the T0 (the initial transformed generation), T1 (the first outcrossed generation), and T2 generations, and are targeted for small horticultural plantings, such as on private properties, arboretums and botanical gardens, historic sites, and parks.

To prepare for potential long-term, largescale forest restoration, we are working closely with TACF on a plan to increase genetic diversity and local adaptation throughout the American chestnut's range (J Westbrook, J Holiday, A Newhouse, et al., in prep). This plan will produce more diverse trees for larger scale restorations such as mine lands and forest ecosystems. 
W.A. Powell et al.

These will be T3 (and later) outcross generations, ultimately incorporating hundreds of mother trees from diverse geographic and genetic backgrounds.

\section{CONCLUDING REMARKS}

Using the American chestnut as a model, we have demonstrated that GE is a viable tool to safely and effectively address invasive pathogens. GE can have several advantages compared to alternative approaches. In American chestnut, it allowed us to develop a blight-tolerant tree while avoiding problems such as IKB (Fulbright et al. 2014), male sterility (Sisco et al. 2014), and intermediate traits (Cipollini et al. 2017) that have arisen from hybrid breeding of chestnuts. GE retains all the genes from the wild tree to help it reintegrate into its natural habitat and restore its ecological services to the forest. Using a single, dominant blight-tolerant gene with an easy identification assay simplifies the rescue of the surviving genetic diversity and lo$\mathrm{cal}$ adaptations. And in the case of OxO or similar traits that do not kill a pathogen, it provides a more evolutionarily stable protection from the blight. This tool can be used alone or combined with more traditional breeding methods, such as stacking the resistance genes incorporated from C. mollissima with $\mathrm{OxO}$ to enhance sustainability even further, or adding Phytophthora resistance, while at the same time making the backcross trees with a greater portion of American chestnut alleles and better adapted to its habitat.

We are on the cusp of the most exciting stage of the American chestnut project, the potential beginning of restoration. Moving from greenhouse and confined field trials to broader plantings in forest conditions will present challenges, but also expand unique research possibilities. We will move from transgene characterization and developing pest tolerance into ecological questions such as how a keystone or foundational tree species (Ellison et al. 2005) can be established back into a dynamic ecosystem. Meanwhile, we will continue to develop new transgenic events, testing regulated promoters and additional genes for other diseases such as
Phytophthora root rot. We also hope to apply what we have learned to other threatened trees such as the Ozark Chinquapin and the American elm. There are many threats to trees and other wild plants, but if we use all the tools available, including GE, there is better hope for the future of our shared environment.

\section{ACKNOWLEDGMENTS}

A special thanks to Dr. Charles Maynard, who was the co-Director of the project for over 26 years and whose insights, encouragement, and hard work helped make the project a success. We thank The American Chestnut Foundation, The Templeton World Charity Fund, Inc., New York State Legislature, USDA Biotechnology Risk Assessment Grants (BRAG) program, and the many public donors to the 10,000 Chestnut Challenge, who have helped fund this project. We also thank all the many collaborators, researchers, students, and volunteers who made this project possible over the past 29 years. The opinions expressed in this publication are those of the authors and may not necessarily reflect the views of the funders.

\section{REFERENCES}

Aguilar C, Urzúa U, Koenig C, Vicuña R. 1999. Oxalate oxidase from Ceriporiopsis subvermispora: Biochemical and cytochemical studies. Arch Biochem Biophys 366: 275-282. doi:10.1006/abbi.1999.1216

Anagnostakis SL. 1982. Biological control of chestnut blight. Science 215: 466-471. doi:10.1126/science.215.4532.466

Anagnostakis SL. 1987. Chestnut blight: The classical problem of an introduced pathogen. Mycologia 79: 23-37. doi:10.1080/00275514.1987.12025367

Anagnostakis SL. 2012. Chestnut breeding in the United States for disease and insect resistance. Plant Dis 96: 1392-1403. doi:10.1094/PDIS-04-12-0350-FE

Anagnostakis SL, Hillman B. 1992. Evolution of the chestnut tree and its blight. Arnoldia 52: 2-10.

Anjum S, Sundaram S, Kumar Rai G. 2014. Banana peel oxalate oxidase-detection, purification, characterization and physiological role. J Pharm Pharm Sci 7: 332-339.

Brogue K, Chet I, Holliday M, Cressman R, Biddle P, Knowlton S, Mauvais CJ, Broglie R. 1991. Transgenic plants with enhanced resistance to the fungal pathogen Rhizoctonia solani. Science 254: 1194-1197. doi:10.1126/science.254 .5035 .1194 
Burnham CR, Rutter PA, French DW. 1986. Breeding blightresistant chestnuts. Plant Breed Rev 4: 347-397. doi:10 .1002/9781118061015.ch11

Burnworth E. 2002. A brief history of the efforts by Stronghold, Inc. to restore the American Chestnut, 1969 to the present. Stronghold, Inc., Sugarloaf Mountain, Dickerson, MD.

Carrillo MGC, Goodwin PH, Leach JE, Leung H, Vera Cruz CM. 2009. Phylogenomic relationships of rice oxalate oxidases to the cupin superfamily and their association with disease resistance QTL. Rice 2: 67-79. doi:10.1007/ s12284-009-9024-0

Cessna SG, Sears VE, Dickman MB, Low PS. 2000. Oxalic acid, a pathogenicity factor for Sclerotinia sclerotiorum suppresses the oxidative burst of the host plant. Plant Cell 12: 2191-2199. doi:10.1105/tpc.12.11.2191

Chen C, Sun Q, Narayanan B, Nuss DL, Herzberg O. 2010. Structure of oxalacetate acetylhydrolase, a virulence factor of the chestnut blight fungus. J Biol Chem 285: 2668526696. doi:10.1074/jbc.M110.117804

Cipollini M, Royce Dingley N, Felch P, Maddox C. 2017. Evaluation of phenotypic traits and blight-resistance in an American chestnut backcross orchard in Georgia. Glob Ecol Conserv 10: 1-8. doi:10.1016/j.gecco.2017.01.004

Collins RJ, Copenheaver CA, Kester ME, Barker EJ, Goldbeck DeBose K. 2017. American chestnut: Re-examining the historical attributes of a lost tree. J Forestry 116: 68-75. doi:10.5849/JOF-2016-014

Curry HA. 2014. Radiation and restoration; or, how best to make a blight-resistant chestnut tree. Environ Hist 19: 217-238. doi:10.1093/envhis/emu001

Dahiya T, Yadav S, Chauhan P, Handa P, Pundir CS. 2010 Strawberry fruit oxalate oxidase-Detection, purification, characterization and physiological role. J Plant Biochem Biotechnol 19: 247-250. doi:10.1007/BF03263349

Dalgleish H, Nelson C, Scrivani J, Jacobs D. 2015. Consequences of shifts in abundance and distribution of American chestnut for restoration of a foundation forest tree. Forests 7: 4. doi:10.3390/f7010004

Davis DE. 2005. Historical significance of American chestnut to Appalachian culture and ecology. In Proc. of Conf. on Restoration of American Chestnut to Forest Lands (ed. Steiner KC, Carlson JE). North Carolina Arboretum, Asheville, NC.

Davoine C, Le Deunff E, Ledger N, Avice JC, Billard JP, Dumas B, Huault C. 2001. Specific and constitutive expression of oxalate oxidase during the ageing of leaf sheaths of ryegrass stubble. Plant Cell Environ 24: 1033-1043. doi:10.1046/j.1365-3040.2001.00757.x

Diamond SJ, Giles RH Jr, Kirkpatrick RL, Griffin GJ. 2000. Hard mast production before and after the chestnut blight. South J Appl For 24: 196-201.

Dietz A. 1978. The use of ionizing radiation to develop a blight resistant American chestnut, Castanea dentata through induced mutations. In Proceedings of the American Chestnut Symposium (ed. MacDonald WL, et al.), pp. 17-20. West Virginia Univ. Press, Morgantown, WV.

Diller JD. 1965. Chestnut blight. US Department of Agriculture, Forest Service, Washington, DC.

Diller JD, Clapper RB. 1969. Asiatic and hybrid chestnut trees in the eastern United States. J Forestry 67: 328-331.
Diskin M, Steiner KC, Hebard FV. 2006. Recovery of American chestnut characteristics following hybridization and backcross breeding to restore blight-ravaged Castanea dentata. For Ecol Manage 223: 439-447. doi:10.1016/j foreco.2005.12.022

Donaldson PA, Anderson T, Lane BG, Davidson AL, Simmonds DH. 2001. Soybean plants expressing an active oligomeric oxalate oxidase from the wheat gf- 2.8 (ger$\mathrm{min}$ ) gene are resistant to the oxalate-secreting pathogen Sclerotina sclerotiorum. Physiol Mol Plant Pathol 59: 297307. doi:10.1006/pmpp.2001.0369

Du X, Ren X, Wang L, Yang K. 2018. Calcium oxalate degradation is involved in aerenchyma formation in Typha angustifolia leaves. Funct Plant Biol 45: 922-934. doi:10 .1071/FP17349

Dukes JS, Pontius J, Orwig D, Garnas JR, Rodgers VL, Brazee N, Cooke B, Theoharides KA, Stange EE, Harrington R, et al. 2009. Responses of insect pests, pathogens, and invasive plant species to climate change in the forests of northeastern North America: What can we predict? Can J For Res 39: 231-248. doi: 10.1139/X08-171

Ellison AM, Bank MS, Clinton BD, Colburn EA, Elliott K, Ford CR, Foster DR, Kloeppel BD, Knoepp JD, Lovett GM, et al. 2005. Loss of foundation species: Consequences for the structure and dynamics of forested ecosystems. Front Ecol Environ 3: 479-486. doi:10.1890/1540-9295 (2005)003[0479:LOFSCF]2.0.CO;2

Freitas CDT, Freitas DC, Cruz WT, Porfirio CTMN, Silva MZR, Oliveiera JS, Carvalho CPS, Ramos MV. 2017. Identification and characterization of two germin-like proteins with oxalate oxidase activity from Calotropis procera latex. Int J Biol Macromol 105: 1051-1061. doi:10 $.1016 /$ j.ijbiomac.2017.07.133

Fu JY, Wang XC, Mao TF, Cheng H, Chen F, Yang YJ. 2018. Identification and functional analysis of germin-like protein Gene family in tea plant (Camellia sinensis). Sci Hortic 234: 166-175. doi:10.1016/j.scienta.2018.02.024

Fuernkranz HA, Nowak CA, Maynard CA. 1990. Light effects on in vitro adventitious root formation in axillary shoots of mature Prunus serotina. Physiol Plant 80: 337341. doi:10.1111/j.1399-3054.1990.tb00050.x

Fulbright DW, Stadt S, Medina-Mora C, Mandujano M, Donis-González IR, Serdar U. 2014. Kernel breakdown appears when hybrid Castanea cultivars are pollinized by Castanea mollissima. Acta Hortic 1019: 91-97. doi:10 .17660/ActaHortic.2014.1019.14

Gesteira AS, Micheli F, Carels N, Da Silva AC, Gramacho KP, Schuster I, Macêdo JN, Pereira GA, Cascardo JC. 2007. Comparative analysis of expressed genes from cacao meristems infected by Moniliophthora perniciosa. Ann Bot 100: 129-140. doi:10.1093/aob/mcm092

Gobbi E, Wang Y, Martin RM, Powell WA, Vanalfen JK. 1990. Mitochondrial DNA of Cryphonectria parasitica: Lack of migration between vegetatively compatible strains. Mol Plant Microbe Interact 3: 66-71. doi:10 .1094/MPMI-3-066

Goldspiel HB, Newhouse AE, Powell WA, Gibbs JP. 2018. Effects of transgenic American chestnut leaf litter on growth and survival of wood frog larvae. Restor Ecol 27: 371-378. doi:10.1111/rec.12879

Gordon YJ, Romanowski EG. 2005. A review of antimicrobial peptides and their therapeutic potential as anti-infec- 
W.A. Powell et al.

tive drugs. Curr Eye Res 30: 505-515. doi:10.1080/ 02713680590968637

Goyal L, Thakur M, Shekhar Pundir C. 1999. Purification and properties of a membrane bound oxalate oxidase from Amaranthus leaves. Plant Sci 142: 21-28. doi:10 $.1016 /$ S0168-9452(98)00251-9

Graves AH. 1940. Breeding work toward the development of a timber type of blight-resistant chestnut. Report for 1939. Bull Torrey Bot Club 67: 773. doi:10.2307/2481530

Hansen DR, Van Alfen NK, Gillies K, Powell WA. 1985. Naked dsRNA associated with hypovirulence of Endothia parasitica is packaged in fungal vesicles. J Gen Virol 66: 2605-2614. doi:10.1099/0022-1317-66-12-2605

Hardin JW, Leopold DJ, White FM. 2001. Harlow and Harrar's textbook of dendrology. McGraw-Hill, New York.

Havir EA, Anagnostakis SL. 1983. Oxalate production by virulent but not by hypovirulent strains of Endothia parasitica. Physiol Plant Pathol 23: 369-376. doi:10.1016/ 0048-4059(83)90021-8

Havir EA, Anagnostakis SL. 1985. Oxaloacetate acetylhydrolase activity in virulent and hypovirulent strains of Endothia (Cryphonectria) parasitica. Physiol Plant Pathol 26: 1-9. doi:10.1016/0048-4059(85)90026-8

He X, Miyasaka SC, Fitch MMM, Khuri S, Zhu YJ. 2013 Taro (Colocasia esculenta) transformed with a wheat oxalate oxidase gene for improved resistance to taro pathogen Phytophthora colocasiae. HortScience 48: 22-27. doi:10.21273/HORTSCI.48.1.22

Hepting GH. 1974. Death of the American chestnut. J For Hist 18: 61-67. doi:10.2307/3983346

Houget J, Mayer A, Plantefol L. 1927. Sur une forme particuliére d'oxydation biologique. Compt Rend 185: 304-306.

Hu S, Bidney DL, Yalpani N, Duvick JP, Crasta O, Folkerts O, Lu G. 2003. Overexpression of a gene encoding hydrogen peroxide-generating oxalate oxidase evokes defense responses in sunflower. Plant Physiol 133: 170-181. doi:10.1104/pp.103.024026

Hu J, Telenko DEP, Phipps PM, Hills H, Grabau EA. 2015 Quantifying transgene flow rate in transgenic Sclerotiniaresistant peanut lines. Field Crops Res 178: 69-76. doi:10 $.1016 /$ j.fcr.2015.03.016

Hu J, Telenko DE, Phipps PM, Grabau EA. 2016. Comparative susceptibility of peanut genetically engineered for Sclerotinia blight resistance to non-target peanut pathogens. Eur J Plant Pathol 145: 177-187. doi:10.1007/ s10658-015-0831-4

Hunt K, Gold M, Reid W, Warmund M. 2012. Growing Chinese chestnuts in Missouri. University of Missouri Center for Agroforestry, Columbia, MO.

Jacobs DF, Selig MF, Severeid LR. 2009. Aboveground carbon biomass of plantation-grown American chestnut (Castanea dentata) in absence of blight. For Ecol Manage 258: 288-294. doi:10.1016/j.foreco.2009.04.014

Jaynes RA. 1967. Natural regeneration from a 40-year old Chinese chestnut planting. J For 65: 29-31.

Jia X, Patrzykat A, Devlin RH, Ackerman PA, Iwama GK, Hancock RE. 2000. Antimicrobial peptides protect coho salmon from Vibrio anguillarum infections. Appl Environ Microbiol 66: 1928-1932. doi:10.1128/AEM.66.5.19281932.2000
Koyama H. 1988. Purification and characterization of oxalate oxidase from Pseudomonas sp. OX-53. Agric Biol Chem 52: 743-748. doi:10.1271/bbb1961.52.743

Kubisiak TL, Hebard FV, Nelson CD, Zhang J, Bernatzky R, Huang H, Anagnostakis SL, Doudrick RL. 1997. Molecular mapping of resistance to blight in an interspecific cross in the genus Castanea. Phytopathology 87: 751759. doi:10.1094/PHYTO.1997.87.7.751

Kumar K, Belur PD. 2016. New extracellular thermostable oxalate oxidase produced from endophytic Ochrobactrum intermedium CL6: Purification and biochemical characterization. Prep Biochem Biotechnol 46: 734-739. doi:10 $.1080 / 10826068.2015 .1135458$

Laker MF, Hofmann AF, Meeuse BJ. 1980. Spectrophotometric determination of urinary oxalate with oxalate oxidase prepared from moss. Clin Chem 26: 827-830.

Lamberty M, Zachary D, Lanot R, Bordereau C, Robert A, Hoffmann JA, Bulet P. 2001. Insect immunity constitutive expression of a cysteine-rich antifungal and a linear antibacterial peptide in a termite insect. $J$ Biol Chem 276: 4085-4092. doi:10.1074/jbc.M002998200

Lane BG, Bernier F, Dratewka-Kos E, Shafai R, Kennedy TD, Pyne C, Munro JR, Vaughan T, Walters D, Altomare F. 1991. Homologies between members of the germin gene family in hexaploid wheat and similarities between these wheat germins and certain Physarum spherulins. J Biol Chem 266: 10461-10469.

Lane BG, Dunwell JM, Ray JA, Schmitt MR, Cuming AC. 1993. Germin, a protein marker of early plant development, is an oxalate oxidase. J Biol Chem 268: 1223912242.

Laties GG. 1950. An oxidative, cyanide-insensitive enzyme system in the chloroplasts of a higher plant. Arch Biochem 27: 404-409.

Liang H, Maynard CA, Allen RD, Powell WA. 2001. Increased Septoria musiva resistance in transgenic hybrid poplar leaves expressing a wheat oxalate oxidase gene. Plant Mol Biol 45: 619-629. doi:10.1023/A:1010 631318831

Liang H, Catranis CM, Maynard CA, Powell WA. 2002. Enhanced resistance to the poplar fungal pathogen, Septoria musiva, in hybrid poplar clones transformed with genes encoding antimicrobial peptides. Biotechnol Lett 24: 383389. doi:10.1023/A:1014552503140

Liang H, Zhebentyayeva T, Olukolu B, Wilde D, Reighard GL, Abbott A. 2010. Comparison of gene order in the chromosome region containing a TERMINAL FLOWER 1 homolog in apricot and peach reveals microsynteny across angiosperms. Plant Sci 179: 390-398. doi:10 .1016/j.plantsci.2010.06.018

Linde A, Ross CR, Davis EG, Dib L, Blecha F, Melgarejo T. 2008. Innate immunity and host defense peptides in veterinary medicine. J Vet Intern Med 22: 247-265. doi:10 $.1111 / j .1939-1676.2007 .0038 . x$

LOC100841795 oxalate oxidase 1 [Brachypodium distachyon (stiff brome)] - Gene, NCBI. https://www.ncbi.nlm.nih .gov/gene/100841795

LOC103698783 oxalate oxidase 1-like [Phoenix dactylifera (date palm)] - Gene, NCBI. https://www.ncbi.nlm.nih .gov/gene/?term=loc103698783 
LOC107261123 oxalate oxidase GF-3.8-like [Ricinus communis (castor bean)] - Gene, NCBI. https://www.ncbi .nlm.nih.gov/gene/100841795

Lovett GM, Canham CD, Arthur MA, Weathers KC, Fitzhugh RD. 2006. Forest ecosystem responses to exotic pests and pathogens in eastern North America. BioScience 56: 395-405. doi:10.1641/0006-3568(2006)056[0395:FER TEP]2.0.CO;2

Lovett GM, Weiss M, Liebhold AM, Holmes TP, Leung B, Lambert KF, Orwig DA, Campbell FT, Rosenthal J, McCullough DG, et al. 2016. Nonnative forest insects and pathogens in the United States: Impacts and policy options. Ecol Appl 26: 1437-1455. doi:10.1890/15-1176

Maynard CA. 1994. Six-year field test results of micropropagated black cherry (Prunus serotina). In Vitro Cell Dev Biol Plant 30: 64-69. doi:10.1007/BF02632122

Merkle S, Weicko AT, Watson-Pauley BA. 1991. Somatic embryogenesis in American chestnut. Can J For Res 21: 1698-1701. doi:10.1139/x91-235

Milgroom M G, Cortesi P. 2004. Biological control of chestnut blight with hypovirulence: A critical analysis. Annu Rev Phytopathol 42: 311-338. doi:10.1146/annurev.phyto 42.040803.140325

Miller AC, Woeste KE, Anagnostakis SL, Jacobs DF. 2014 Exploration of a rare population of Chinese chestnut in North America: Stand dynamics, health and genetic relationships. AoB Plants 6: plu065. doi:10.1093/aobpla/ plu065

Molla KA, Karmakar S, Chanda PK, Ghosh S, Sarkar SN, Datta SK, Datta K. 2013. Rice oxalate oxidase gene driven by green tissue-specific promoter increases tolerance to sheath blight pathogen (Rhizoctonia solani) in transgenic rice. Mol Plant Pathol 14: 910-922. doi:10.1111/mpp .12055

Newhouse AE, Schrodt F, Liang H, Maynard CA, Powell WA. 2007. Transgenic American elm shows reduced Dutch elm disease symptoms and normal mycorrhizal colonization. Plant Cell Rep 26: 977-987. doi:10.1007/s00299007-0313-Z

Newhouse AE, Polin-McGuigan LD, Baier KA, Valletta KE Rottmann WH, Tschaplinski TJ, Maynard CA, Powell WA. 2014. Transgenic American chestnuts show enhanced blight resistance and transmit the trait to $\mathrm{T} 1 \mathrm{prog}$ eny. Plant Sci 228: 88-97. doi:10.1016/j.plantsci.2014.04 .004

Newhouse AE, Oakes AD, Pilkey HC, Roden HE, Horton TR, Powell WA. 2018. Transgenic American chestnuts do not inhibit germination of native seeds or colonization of mycorrhizal fungi. Front Plant Sci 9: 1046. doi:10.3389/ fpls.2018.01046

Oakes AD, Desmarais TR, Powell WA, Maynard CA. 2016a. Ex vitro rooting of American chestnut improves acclimatization survival and plantlet quality. J Environ Hortic 34: 75-79.

Oakes AD, Desmarais T, Powell WA, Maynard CA. 2016b. Improving rooting and shoot tip survival of micropropagated transgenic American chestnut shoots. HortScience 51: 171-176. doi:10.21273/HORTSCI.51.2.171

Obzansky DM, Richardson KE. 1983. Quantification of urinary oxalate with oxalate oxidase from beet stems. Clin Chem 29: 1815-1819.
Oxalate oxidase GF-2.8 [Triticum urartu] - Protein, NCBI https://www.ncbi.nlm.nih.gov/protein/EMS64919.1

Oxalate oxidase GF-2.8 [Aegilops tauschii subsp. tauschii] Protein, NCBI. https://www.ncbi.nlm.nih.gov/protein/ XP_020157271.1

Paillet FL. 2002. Chestnut: History and ecology of a transformed species. J Biogeogr 29: 1517-1530. doi:10.1046/j 1365-2699.2002.00767.x

Polin LD, Liang H, Rothrock RE, Nishii M, Diehl DL, Newhouse AE, Nairn J, Powell WA, Maynard CA. 2006. Agrobacterium-mediated transformation of American chestnut (Castanea dentata (Marsh.) Borkh.) somatic embryos. Plant Cell Tiss Organ Cult 84: 69-79. doi:10 .1007/s11240-005-9002-1

Powell WA, Van Alfen NK. 1987a. Differential accumulation of poly $(\mathrm{A})^{+}$RNA between virulent and double-stranded RNA-induced hypovirulent strains of Cryphonectria ( $E n$ dothia) parasitica. Mol Cell Biol 7: 3688-3693. doi:10 1128/MCB.7.10.3688

Powell WA, Van Alfen NK. 1987b. Two nonhomologus viruses of Cryphonectria (Endothia) parasitica reduce accumulation of specific virulence-associated polypeptides. J Bacteriol 169: 5324-5326. doi:10.1128/jb.169.11.53245326.1987

Powell WA, Catranis CM, Maynard CA. 1995. Synthetic antimicrobial peptide design. Mol Plant Microbe Interact 8: 792-794. doi:10.1094/MPMI-8-0792

Powell WA, Catranis CM, Maynard CA. 2000. Design of selfprocessing antimicrobial peptides for plant protection. Lett Appl Microbiol 31: 163-168. doi:10.1046/j.13652672.2000.00782.x

Ramputh AI, Arnason JT, Cass L, Simmonds JA. 2002. Reduced herbivory of the European corn borer (Ostrinia nubilalis) on corn transformed with germin, a wheat oxalate oxidase gene. Plant Sci 162: 431-440. doi:10.1016/ S0168-9452(01)00584-2

Rausher MD. 2001. Co-evolution and plant resistance to natural enemies. Nature 411: 857. doi:10.1038/35081193

Rothrock RE, Polin-McGuigan LD, Newhouse AE, Powell WA, Maynard CA. 2007. Plate flooding as an alternative Agrobacterium-mediated transformation method for American chestnut somatic embryos. Plant Cell Tiss Organ Cult 88: 93-99. doi:10.1007/s11240-006-9170-7

Rusli MH, Idris AS, Cooper RM. 2015. Evaluation of Malaysian oil palm progenies for susceptibility, resistance or tolerance to Fusarium oxysporum f. sp. elaeidis and defence-related gene expression in roots. Plant Pathol 64: 638-647. doi:10.1111/ppa.12301

Sakamoto A, Nishimura T, Miyaki YI, Watanabe S, Takagi H, Izumi S, Shimada H. 2015. In vitro and in vivo evidence for oxalate oxidase activity of a germin-like protein from azalea. Biochem Biophys Res Commun 458: $536-$ 542. doi:10.1016/j.bbrc.2015.02.002

Sathishraj R, Augustin A. 2012. Oxalic acid and oxalate oxidase enzyme in Costus pictus D. Don. Acta Physiol Plant 34: 657-667. doi:10.1007/s11738-011-0866-x

Satyapal CS, Pundir CS. 1993. Purification and properties of an oxalate oxidase from leaves of grain sorghum hybrid CSH-5. Biochim Biophys Acta 1161: 1-5. doi:10.1016/ 0167-4838(93)90188-W 
W.A. Powell et al.

SCHCODRAFT_15706 oxalate oxidase [Schizophyllum commune H4-8] - Gene, NCBI. https://www.ncbi.nlm .nih.gov/gene/?term=schcodraft_15706

Sisco PH, Neel TC, Hebard FV, Craddock JH, Shaw J. 2014. Cytoplasmic male sterility in interspecific hybrids between American and Asian Castanea species is correlated with the American D chloroplast haplotype. Acta Hortic 1019: 215-222. doi:10.17660/ActaHortic.2014.1019.32

Smith DM. 2000. American chestnut: Ill-fated monarch of the eastern hardwood forest. J Forestry 98: 12-15. doi:10 $.1093 /$ jof/98.2.12

Srivastava SK, Krishnan PS. 1962. An oxalic acid oxidase in the leaves of Bougainvillea spectabilis. Biochem J 85: $33-$ 38. doi:10.1042/bj0850033

Stauder CM, Nuss DL, Zhang DX, Double ML, MacDonal WL, Metheny AM, Kasson MT. 2019. Enhanced hypovirus transmission by engineered super donor strains of the chestnut blight fungus, Cryphonectria parasitica, into a natural population of strains exhibiting diverse vegetative compatibility genotypes. Virology 528: 1-6. doi:10.1016/j .virol.2018.12.007

Steiner KC, Westbrook JW, Hebard FV, Georgi LL, Powell WA, Fitzsimmons SF. 2017. Rescue of American chestnut with extraspecific genes following its destruction by a naturalized pathogen. New Forests 48: 317-336. doi:10 .1007/s11056-016-9561-5

Sugiura M, Yamamura H, Hirano K, Sasaki M, Morikawa M, Tusboi M. 1979. Purification and properties of oxalate oxidase from barley seedlings. Chem Pharm Bull 27: 2003-2007. doi:10.1248/cpb.27.2003

TERG_03492 oxalate oxidase [Trichophyton rubrum CBS 118892] - Gene, NCBI. https://www.ncbi.nlm.nih.gov/ gene/?term=terg_03492

Tricoli DM, Maynard CA, Drew AP. 1985. Tissue culture of propagation of mature trees of Prunus serotina Ehrh. I: Establishment, multiplication, and rooting in vitro. For Sci 31: 201-208.

Van Alfen NK. 2018. Hypovirulence of Endothia (Cryphonectria) parasitica and Rhizoctonia solani. In Fungal virology (ed. Buck KW). Taylor \& Francis, New York.

Vuletić M, Šukalović VHT. 2000. Characterization of cell wall oxalate oxidase from maize roots. Plant Sci 157: 257-263. doi:10.1016/S0168-9452(00)00290-9

Walz A, Zingen-Sell I, Loeffler M, Sauer M. 2008. Expression of an oxalate oxidase gene in tomato and severity of disease caused by Botrytis cinerea and Sclerotinia sclerotio- rum. Plant Pathol 57: 453-458. doi: 10.1111/j.1365-3059 .2007.01815.x

Wang T, Zhang E, Chen X, Li L, Liang X. 2010. Identification of seed proteins associated with resistance to pre-harvested aflatoxin contamination in peanut (Arachis hypogaea L). BMC Plant Biol 10: 267. doi:10.1186/1471-2229-10267

Welch AJ, Stipanovic AJ, Maynard CA, Powell WA. 2007. The effects of oxalic acid on transgenic Castanea dentata callus tissue expressing oxalate oxidase. Plant Sci 172: 488-496. doi:10.1016/j.plantsci.2006.10.015

Woodcock P, Cottrell JE, Buggs RJA, Quine CP. 2018. Mitigating pest and pathogen impacts using resistant trees: A framework and overview to inform development and deployment in Europe and North America. Forestry 91: 116. doi:10.1093/forestry/cpx031

Xing Z, Satchwell MF, Powell WA, Maynard CA. 1997. Micropropagation of American chestnut: Increasing rooting rate and preventing shoot-tip necrosis. In Vitro Cell Dev Biol Plant 33: 43-48. doi:10.1007/s11627-997-0039-1

Xing Z, Powell WA, Maynard CA. 1999. Development and germination of American chestnut somatic embryos. Plant Cell Tiss Organ Cult 57: 47-55. doi:10.1023/A: 1006360730898

Xuxia W, Jie C, Bo W, Lijun L, Hui J, Diluo T, Dingxiang P. 2012. Characterization by suppression subtractive hybridization of transcripts that are differentially expressed in leaves of anthracnose-resistant ramie cultivar. Plant Mol Biol Rep 30: 547-555. doi:10.1007/s11105-0110361-y

Yoshikawa M, Tsuda M, Takeuchi Y. 1993. Resistance to fungal diseases in transgenic tobacco plants expressing the phytoalexin elicitor-releasing factor, $\beta$-1, 3-endoglucanase, from soybean. Naturwissenschaften 80: 417-420. doi:10.1007/BF01168337

Zasloff M. 1987. Magainins, a class of antimicrobial peptides from Xenopus skin: Isolation, characterization of two active forms, and partial cDNA sequence of a precursor. Proc Natl Acad Sci 84: 5449-5453. doi:10.1073/pnas.84 .15 .5449

Zhang B, Oakes AD, Newhouse AE, Baier KM, Maynard CA Powell WA. 2013. A threshold level of oxalate oxidase transgene expression reduces Cryphonectria parasiticainduced necrosis in a transgenic American chestnut (Castanea dentata) leaf bioassay. Transgenic Res 22: 973-982. doi:10.1007/s11248-013-9708-5 


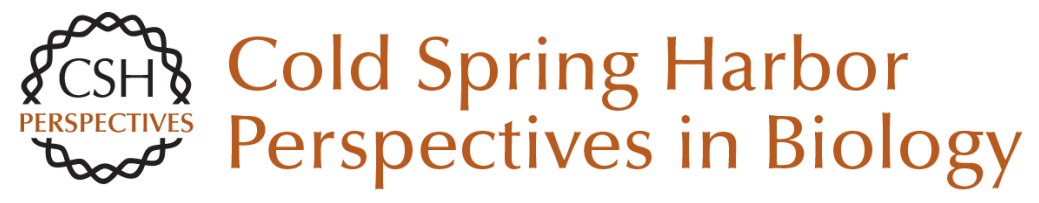

\section{Developing Blight-Tolerant American Chestnut Trees}

William A. Powell, Andrew E. Newhouse and Vernon Coffey

Cold Spring Harb Perspect Biol 2019; doi: 10.1101/cshperspect.a034587 originally published online May 20,2019

\section{Subject Collection Engineering Plants for Agriculture}

Plant Inflorescence Architecture: The Formation, Activity, and Fate of Axillary Meristems Yang Zhu and Doris Wagner

Sub1 Rice: Engineering Rice for Climate Change Kyle Emerick and Pamela C. Ronald

Engineering Disease-Resistant Cassava Z.J. Daniel Lin, Nigel J. Taylor and Rebecca Bart

Many Facets of Dynamic Plasticity in Plants Xiaodong Yang and Sally A. Mackenzie

How Do Strigolactones Ameliorate Nutrient Deficiencies in Plants?

Kaori Yoneyama

Mechanisms and Impact of Symbiotic Phosphate Acquisition Chai Hao Chiu and Uta Paszkowski
The Sweet Side of Plant-Specialized Metabolism Thomas Louveau and Anne Osbourn

The Role of Dwarfing Traits in Historical and Modern Agriculture with a Focus on Rice Ángel Ferrero-Serrano, Christian Cantos and Sarah M. Assmann

Bt Brinjal in Bangladesh: The First Genetically Engineered Food Crop in a Developing Country Anthony M. Shelton, Md. J. Hossain, Vijay Paranjape, et al.

Circadian Rhythms in Plants Nicky Creux and Stacey Harmer

Developing Blight-Tolerant American Chestnut Trees William A. Powell, Andrew E. Newhouse and Vernon Coffey

Stomatal Development and Perspectives toward Agricultural Improvement Hitoshi Endo and Keiko U. Torii

For additional articles in this collection, see http://cshperspectives.cshlp.org/cgi/collection/

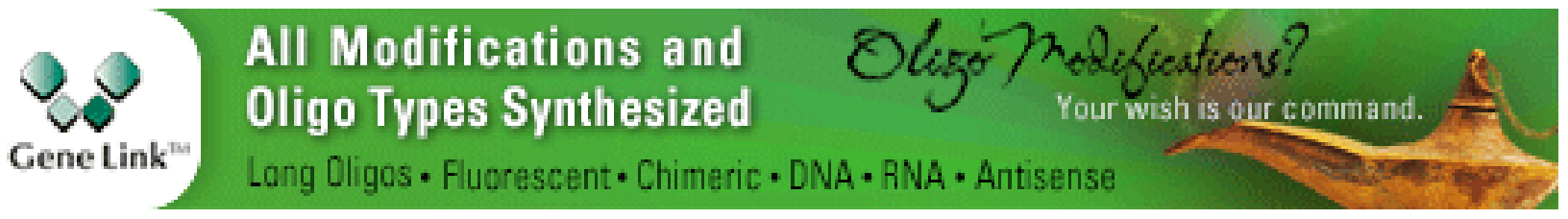

